\title{
Proline as an essential amino acid for the young pig
}

\author{
BY RONALD O. BALL, JAMES L. ATKINSON \\ AND HENRY S. BAYLEY* \\ Department of Nutrition, University of Guelph, Guelph, Ontario, Canada N1G 2WI
}

(Received 2 January 1986 - Accepted 15 January 1986)

\begin{abstract}
1. The catabolism of $\mathrm{L}-\left[1-{ }^{14} \mathrm{C}\right]$ phenylalanine was used to indicate the effects of single amino acid supplementation of an inadequate protein diet $(200 \mathrm{~g}$ crude protein (nitrogen $\times 6.25) / \mathrm{kg}$ ) on the utilization of dietary amino acids in pigs of $2.5 \mathrm{~kg}$ body-weight reared on an adequate protein diet $(240 \mathrm{~g}$ crude protein $/ \mathrm{kg}$ ) containing skim milk and a mixture of free amino acids.

2. The oxidation of phenylalanine was decreased by the addition of proline or arginine to the inadequate protein diet but not by the addition of threonine, methionine, lysine or a mixture of essential amino acids, indicating that proline and arginine were limiting the utilization of dietary amino acids in the inadequate protein diet.

3. Dietary proline concentrations of 13.9 and $14.2 \mathrm{~g} / \mathrm{kg}$ minimized phenylalanine oxidation in diets containing 200 or $260 \mathrm{~g}$ protein $/ \mathrm{kg}$. This indicates a dietary proline requirement of $14 \mathrm{~g} / \mathrm{kg}$.

4. Increasing the dietary arginine concentration in a diet containing 240 g protein $/ \mathrm{kg}$ showed that an arginine concentration of $5 \cdot 1 \mathrm{~g} / \mathrm{kg}$ minimized phenylalanine oxidation. However, increasing the arginine concentration in a diet containing $200 \mathrm{~g}$ protein $/ \mathrm{kg}$ increased phenylalanine oxidation, suggesting an amino acid imbalance involving arginine at this lower level of protein.
\end{abstract}

The Agricultural Research Council (ARC) (1981) lists amino acid requirements on the basis of 'ideal protein' which is derived from the analyses of pig tissue and sow's milk. As a consequence, the protein requirement is that necessary to provide the requirement for the first limiting amino acid. The (US) National Research Council (NRC) (1979) recommends a dietary protein concentration of $270 \mathrm{~g} / \mathrm{kg}$ for the piglet of $1-5 \mathrm{~kg}$ but cautions that a substantial part of this must be provided as cow's milk. Ball \& Bayley (1986) found that a dietary protein concentration of $240 \mathrm{~g} / \mathrm{kg}$ was necessary to minimize catabolism of an indicator amino acid in a diet containing 0.6 of the nitrogen as free amino acids, and concluded that this was the dietary protein concentration necessary to optimize the use of dietary protein for tissue deposition.

Table 1 shows the dietary protein concentrations necessary to provide the recommended levels of the essential amino acids in diets based on cow's milk. The estimates of both protein requirement and amino acid requirements by the NRC (1979) and by the University of Guelph (Kim et al. 1983a, b; Kim \& Bayley, 1983; Ball \& Bayley, 1984, 1986) show a much higher protein requirement than the level necessary to meet the amino acid requirement.

There are three possible explanations for this discrepancy: the essential amino acid requirements may be underestimated, the young pig may have a higher requirement for non-specific amino-N than the growing pig, or some of the amino acids considered non-essential on the basis of work with older pigs may be required in the diet by the young pig. These three possible explanations were examined using the oxidation of phenylalanine as an indicator of the adequacy of the quantity and quality of the dietary protein for the young pig.

\section{EXPERIMENTAL}

Diets and animal management

The animals and experimental procedures have been described by Ball \& Bayley (1986). The piglets were weaned at $3 \mathrm{~d}$ of age and transferred to individual wire cages in the 
Table 1. Level of dietary protein from dried skim milk* required to meet current recommended amino acid requirements $(\mathrm{g} / \mathrm{kg})$ for the pig of $1-5 \mathrm{~kg}$

\begin{tabular}{llcl} 
& ARC & NRC $\dagger$ & Guelph $\ddagger$ \\
\hline Recommended protein level & - & 270 & 240 \\
Arginine & - & 92 & - \\
Histidine & 206 & 116 & 149 \\
Isoleucine & 132 & 123 & - \\
Leucine & 171 & 103 & - \\
Lysine & 198 & 151 & 142 \\
Methionine+cystine & 217 & 196 & 157 \\
Phenylalanine + tyrosine & 193 & 142 & 144 \\
Threonine & 242 & 183 & 161 \\
Tryptophan & 198 & 165 & - \\
Valine & 179 & 129 & - \\
\hline
\end{tabular}

* Containing $335 \mathrm{~g}$ crude protein $/ \mathrm{kg}$ and amino acids as described by Kim et al. (1983b).

† ARC, Agricultural Research Council (1981); NRC, (US) National Research Council (1979).

$\ddagger$ Guelph: Ball \& Bayley $(1984,1986)$; Kim et al. $(1983 a, b)$; Kim \& Bayley (1983).

laboratory where they received six meals/d of a diet containing $240 \mathrm{~g}$ crude protein $(\mathrm{N} \times 6.25) / \mathrm{kg}$, in which 0.4 of the protein was provided by cow's skim milk and 0.6 of the protein as a mixture of free amino acids (Ball \& Bayley, 1986). When the pigs weighed $2.5 \mathrm{~kg}$ they were fasted overnight and then received two meals of the experimental diet, each meal containing $10 \mu \mathrm{Ci} \mathrm{L}-\left[1-{ }^{14} \mathrm{C}\right]$ phenylalanine. These meals were given 4 and $2 \mathrm{~h}$ before a $60 \mathrm{~min}$ collection of expired carbon dioxide. The radioactivity in the $\mathrm{CO}_{2}$ was measured by liquid scintillation counting. At $15 \mathrm{~min}$ after the end of the $\mathrm{CO}_{2}$-collection period the pigs were killed and their livers removed for determination of radioactivity.

The diets used in these studies are outlined in Table 2 . The concentrations of phenylalanine and tyrosine were maintained at 8.8 and $8.5 \mathrm{~g} / \mathrm{kg}$ respectively, except in the second part of Expt 2 when the concentrations were increased to 10.7 and $10.2 \mathrm{~g} / \mathrm{kg}$ respectively, to increase the rates of phenylalanine oxidation in the diet containing the excess dietary protein.

\section{Expt 1. Determination of limiting amino acids in a diet containing an inadequate concentration of protein}

The first experiment was designed to examine why piglets require $240 \mathrm{~g}$ protein $/ \mathrm{kg}$ (Ball \& Bayley, 1986) when their requirements for essential amino acids would be met in diets containing no more than $200 \mathrm{~g}$ protein from skim milk/kg (NRC, 1979). A diet containing an inadequate dietary protein concentration was supplemented with either single essential amino acids which may have been limiting, or a mixture of non-essential amino acids. The diet contained $200 \mathrm{~g}$ protein $/ \mathrm{kg}$ and the amino acids were added to increase the amino acid concentration up to the level in the diet containing $240 \mathrm{~g}$ protein $/ \mathrm{kg}$, which had previously been shown to minimize phenylalanine catabolism (Ball \& Bayley, 1986).

\section{Expt 2. Influence of dietary proline concentration}

This experiment was designed to measure the dietary concentration of proline which would minimize phenylalanine catabolism. The first part of this experiment was carried out with a diet containing an inadequate protein level $(200 \mathrm{~g} / \mathrm{kg})$, and this was supplemented with 
Table 2. Details of experimental diets*

\begin{tabular}{|c|c|c|c|c|c|}
\hline \multirow{2}{*}{$\begin{array}{l}\text { Expt no.... } \\
\text { Dietary protein }(g / \mathrm{kg}) \ldots\end{array}$} & \multirow{2}{*}{$\begin{array}{r}1 \\
200\end{array}$} & \multicolumn{2}{|c|}{2} & \multicolumn{2}{|c|}{3} \\
\hline & & 200 & 260 & 200 & 240 \\
\hline \multicolumn{6}{|l|}{ Ingredients $(\mathrm{g} / \mathrm{kg})$; } \\
\hline Dried skim milk & 296 & 296 & 296 & 296 & 296 \\
\hline Glucose & $345 \cdot 5$ & 345.5 & $278 \cdot 7$ & $345 \cdot 5$ & 301 \\
\hline Maize oil & 200 & 200 & 200 & 200 & 200 \\
\hline Minerals & $\mathbf{4 4} \cdot 5$ & $44 \cdot 5$ & 44.5 & 44.5 & $44 \cdot 5$ \\
\hline Vitamins & $2 \cdot 5$ & 2.5 & 2.5 & $2 \cdot 5$ & $2 \cdot 5$ \\
\hline Amino acid mixture & $111 \cdot 5$ & 111.5 & $178 \cdot 3$ & $111 \cdot 5$ & 156 \\
\hline Experimental variable & $\dagger$ & $\ddagger$ & $\S$ & | & $\pi$ \\
\hline
\end{tabular}

Composition of amino acid mixture $(\mathrm{g} / \mathrm{kg})$

Essential amino acids

$\begin{array}{ll}\text { Arginine } & 32.7 \\ \text { Histidine } & 24.4 \\ \text { Isoleucine } & 63 \cdot 5 \\ \text { Leucine } & 91 \cdot 0 \\ \text { Lysine hydrochloride } & 77 \cdot 6 \\ \text { Methionine } & 22.4 \\ \text { Cystine } & 14 \cdot 1 \\ \text { Phenylalanine } & 41 \cdot 0 \\ \text { Tyrosine } & 35 \cdot 9 \\ \text { Threonine } & 38.5\end{array}$

Non-essential amino acids Alanine $\quad 53.2$

Aspartic acid $\quad 33.9$

Asparagine $\quad 33.9$

Glutamic acid $\quad 104.5$

Glutamine $\quad 104 \cdot 5$

Glycine $\quad 104 \cdot 5$

Proline 26.3

Serine $\quad 26 \cdot 3$

* For details of suppliers and for composition of mineral and vitamin supplements see Ball \& Bayley (1986).

$\dagger$ Supplemented $(\mathrm{g} / \mathrm{kg}$ ) with either methionine 1.01 , threonine 1.67 , lysine 3.35 , arginine 1.43 , proline 1.30 or a non-essential amino acid mixture $40 \cdot 0$ (alanine $4 \cdot 6$, aspartic acid 2.96 , asparagine 2.96 , glutamic acid 9.04 , glutamine $9 \cdot 04$, glycine $9 \cdot 12$, serine $2 \cdot 28$ ).

$\ddagger$ Supplemented with graded levels of proline.

$\S$ Supplemented with graded levels of proline. Proline was eliminated from the amino acid mixture and replaced with glucose.

|| Supplemented with proline to total $14.4 \mathrm{~g} / \mathrm{kg}$ and graded levels of arginine.

Supplemented with graded levels of arginine. Arginine was eliminated from the amino acid mixture and replaced with glucose.

proline to equal the concentration found in semi-synthetic diets containing 200,210, 220, 240 and $280 \mathrm{~g}$ protein $/ \mathrm{kg}$. This study was repeated with a diet containing an excess of protein $(260 \mathrm{~g} / \mathrm{kg})$ to ensure that the response was due to proline supplementation and not to the amino- $\mathrm{N}$ provided by the proline. The proline concentrations investigated were equivalent to those in the semi-synthetic diets containing 173, 238, 301 and $385 \mathrm{~g}$ protein $/ \mathrm{kg}$.

\section{Expt 3. Influence of dietary arginine concentration}

The effect of dietary arginine concentration on phenylalanine oxidation was studied in diets containing adequate proline $(14.4 \mathrm{~g} / \mathrm{kg})$ and either inadequate $(200 \mathrm{~g} / \mathrm{kg})$ or adequate $(240 \mathrm{~g} / \mathrm{kg})$ protein. The diet with the inadequate protein concentration was supplemented with L-arginine free base to give arginine concentrations equivalent to those in diets containing $200,220,240$ and $280 \mathrm{~g}$ protein $/ \mathrm{kg}$. The diet with the adequate protein concentration was supplemented to give arginine concentrations equivalent to those in the semi-synthetic diets containing 120, 140, 160, 200 and $280 \mathrm{~g}$ protein $/ \mathrm{kg}$. 
Table 3. Effect of amino acid additions to a diet containing an inadequate level of protein $(200 \mathrm{~g} / \mathrm{kg})$ on $\left[{ }^{14} \mathrm{C}\right]$ phenylalanine oxidation and incorporation into liver tissue

\begin{tabular}{|c|c|c|c|c|c|c|c|}
\hline Supplement & Control & Threonine & $\begin{array}{l}\text { Methio- } \\
\text { nine }\end{array}$ & Lysine & $\begin{array}{l}\text { Non- } \\
\text { essential } \\
\text { amino } \\
\text { acids }\end{array}$ & Proline & Arginine \\
\hline Level of addition $\dagger(\mathrm{g} / \mathrm{kg})$ & - & 1.67 & 1.01 & $3 \cdot 35$ & $40 \cdot 0$ & $1 \cdot 30$ & 1.43 \\
\hline No. of piglets & 5 & 4 & 4 & 4 & 5 & 4 & 6 \\
\hline $\begin{array}{l}\text { Radioactivity in expired } \\
\text { carbon dioxide } \\
\text { (disintegrations } / \mathrm{min} \\
\text { per } \mathrm{kg} \text { ) }\end{array}$ & 1000 & $1006 \mathrm{NS}$ & $978 \mathrm{NS}$ & $1032 \mathrm{NS}$ & $828 \mathrm{NS}$ & $681^{*}$ & $744^{*}$ \\
\hline SE & 96 & 85 & 107 & 114 & 62 & 65 & 98 \\
\hline $\begin{array}{l}\text { Radioactivity in liver } \\
\text { (disintegrations/min } \\
\text { per } \mathrm{mg} \text { ) }\end{array}$ & 48 & $48 \mathrm{NS}$ & $45 \mathrm{NS}$ & $44 N S$ & $44 \mathrm{NS}$ & $43 \mathrm{NS}$ & $44 N S$ \\
\hline $\mathrm{SE}$ & 5 & 4 & 3 & 3 & 2 & 2 & 2 \\
\hline
\end{tabular}

NS, not significantly different from the unsupplemented diet $(P>0.05)$.

* Means within rows were significantly different from the unsupplemented diet $(P<0.05)$.

$\dagger$ The amino acids were added to equal the concentration of each contained in a diet previously shown to meet the protein requirement $(240 \mathrm{~g} / \mathrm{kg}$, Ball \& Bayley, 1986).

\section{Statistical analysis}

The effects of the amino acid supplementation in Expt 1 were compared with the unsupplemented diet using Student's $t$ test (Steel \& Torrie, 1960). The response to graded additions of proline and arginine in Expts 2 and 3 were analysed, where appropriate, by the linear regression model described by Kim et al. (1983b).

\section{RESULTS}

Supplementation of the diet containing an inadequate $(200 \mathrm{~g} / \mathrm{kg})$ concentration of protein, with methionine, threonine or lysine, did not reduce the oxidation of phenylalanine (Table 3) suggesting that these amino acids were not limiting. However, the addition of the mixture of non-essential amino acids did reduce phenylalanine oxidation, although this effect was significant only at $P<0 \cdot 1$. In contrast, additions of either proline or arginine significantly reduced phenylalanine oxidation $(P<0.05)$, showing that the utilization of an essential amino acid (phenylalanine) for protein deposition was increased, and suggesting that these two amino acids may be limiting in these diets for the young pig. Recovery of radioactivity in the liver was not influenced by any of the dietary treatments.

\section{Effects of dietary proline concentration}

Increasing the dietary proline concentration from $13 \cdot 1$ to $14.4 \mathrm{~g} / \mathrm{kg}$ reduced phenylalanine oxidation but a further increase to $15.7 \mathrm{~g} / \mathrm{kg}$ had no effect (Fig. 1). Analysis of the results showed that phenylalanine oxidation was minimized with a dietary proline concentration of $13.9 \mathrm{~g} / \mathrm{kg}(95 \%$ confidence interval of $13.8-14 \cdot 1)$ in the diet containing $200 \mathrm{~g}$ protein $/ \mathrm{kg}$. Repeating the determination using a diet containing an excess of protein $(260 \mathrm{~g} / \mathrm{kg})$ produced a similar result (Fig. 2): increasing proline from 12.2 to $14.2 \mathrm{~g} / \mathrm{kg}$ reduced phenylalanine oxidation with no further reduction being associated with higher concentrations of proline. The close agreement between the two estimates shows that the response was to the proline itself rather than to its amino-N. 


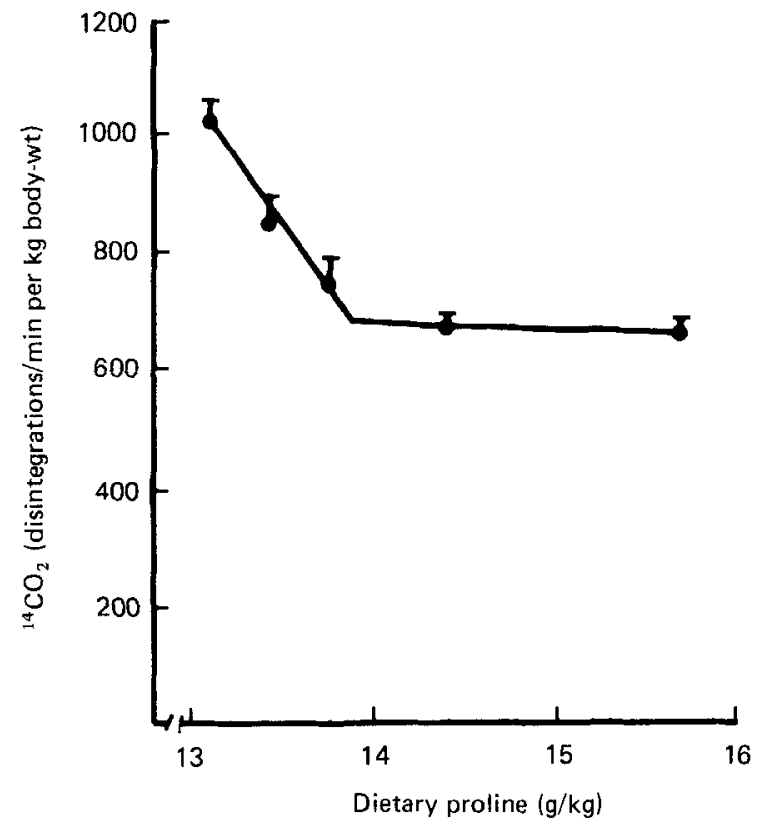

Fig. 1. Influence of proline concentration in a diet containing $200 \mathrm{~g}$ crude protein (nitrogen $\times 6 \cdot 25) / \mathrm{kg}$ on the oxidation of phenylalanine. Means with their standard errors, represented by vertical bars, for the radioactivity recovered as carbon dioxide in $1 \mathrm{~h}$ from pigs which had received two meals after an overnight fast. Each meal contained $10 \mu \mathrm{Ci} \mathrm{L}-[1-14 \mathrm{C}]$ phenylalanine, $8.8 \mathrm{~g}$ phenylalanine $/ \mathrm{kg}$, $8.5 \mathrm{~g}$ tyrosine $/ \mathrm{kg}$ and graded levels of proline $(13 \cdot 1,13 \cdot 5,13 \cdot 8,14 \cdot 4,15 \cdot 7 \mathrm{~g} / \mathrm{kg})$. Each point represents the mean of four piglets. Lines were fitted by regression analysis. The means (with $\mathrm{SE}$ ) for weight, age and growth rate of the piglets were $2.54(0.02) \mathrm{kg}, 10 \cdot 9(0.30) \mathrm{d}$ and $139(5.5) \mathrm{g} / \mathrm{d}$ respectively.

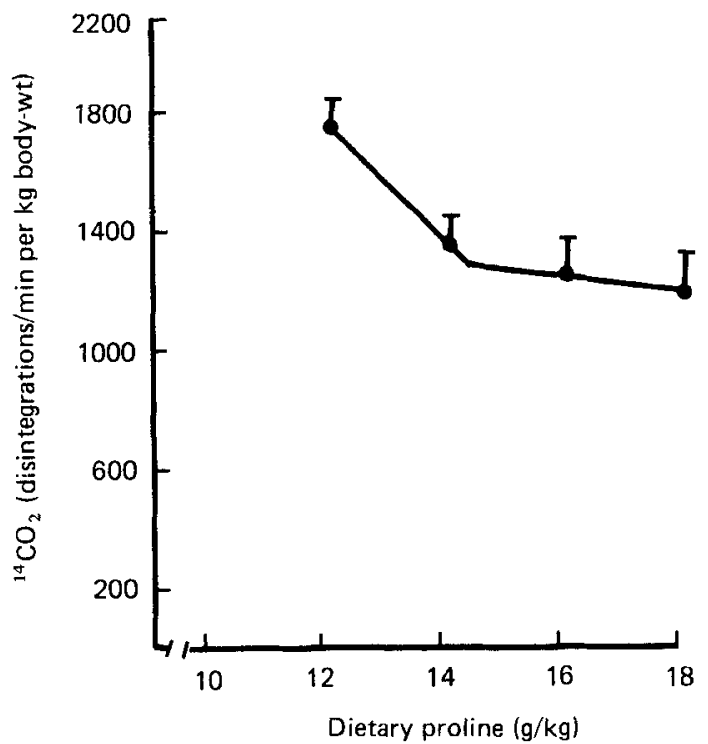

Fig. 2. Influence of proline concentration in a diet containing $260 \mathrm{~g}$ crude protein $($ nitrogen $\times 6 \cdot 25) / \mathrm{kg}$ on the oxidation of phenylalanine. Means with their standard errors, represented by vertical bars, for the radioactivity recovered as carbon dioxide in $\mathrm{I} h$ from pigs which had received two meals after an overnight fast. Each meal contained $10 \mu \mathrm{Ci} \mathrm{L}-\left[1-{ }^{14} \mathrm{C}\right]$ phenylalanine, $10.7 \mathrm{~g}$ phenylalanine $/ \mathrm{kg}$, $10.2 \mathrm{~g}$ tyrosine $/ \mathrm{kg}$ and graded levels of proline $(12 \cdot 2,14 \cdot 2,16 \cdot 2,18.2 \mathrm{~g} / \mathrm{kg})$. Each point represents the mean of three piglets except level $12 \cdot 2$ ( $n$ 5). The means (with SE) for weight, age and growth rate of the piglets were $2.50(0.03) \mathrm{kg}, 10 \cdot 8(0.43) \mathrm{d}$ and $150(6 \cdot 1) \mathrm{g} / \mathrm{d}$ respectively. 


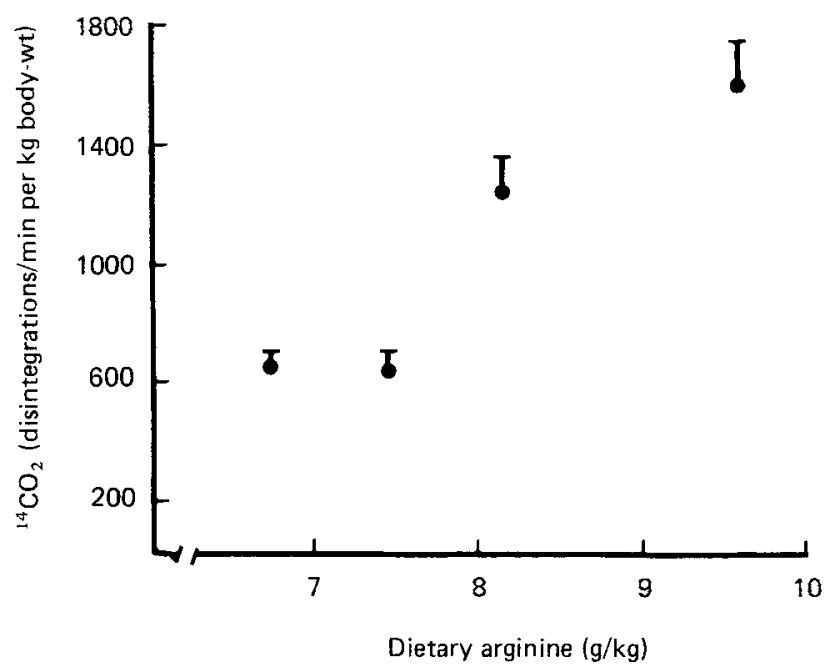

Fig. 3. Influence of arginine concentration in a diet containing $200 \mathrm{~g}$ crude protein (nitrogen $\times 6 \cdot 25) / \mathrm{kg}$ and $14.4 \mathrm{~g}$ proline $/ \mathrm{kg}$ on the oxidation of phenylalanine. Means with their standard errors, represented by vertical bars, for the radioactivity recovered as carbon dioxide in $1 \mathrm{~h}$ from pigs which had received two meals after an overnight fast. Each meal contained $10 \mu \mathrm{Ci} \mathrm{L}-\left[1-{ }^{14} \mathrm{C}\right]$ phenylalanine, $8.8 \mathrm{~g}$ phenylalanine $/ \mathrm{kg}, 8.5 \mathrm{~g}$ tyrosine $/ \mathrm{kg}$ and graded levels of arginine $(6.8,7.5,8.2,9.6 \mathrm{~g} / \mathrm{kg})$. Each point represents the mean of three piglets. The means (with SE) for weight, age and growth rate of the piglets were $2.49(0.05) \mathrm{kg}, 11 \cdot 2(0 \cdot 70) \mathrm{d}$ and $145(9 \cdot 0) \mathrm{g} / \mathrm{d}$ respectively.

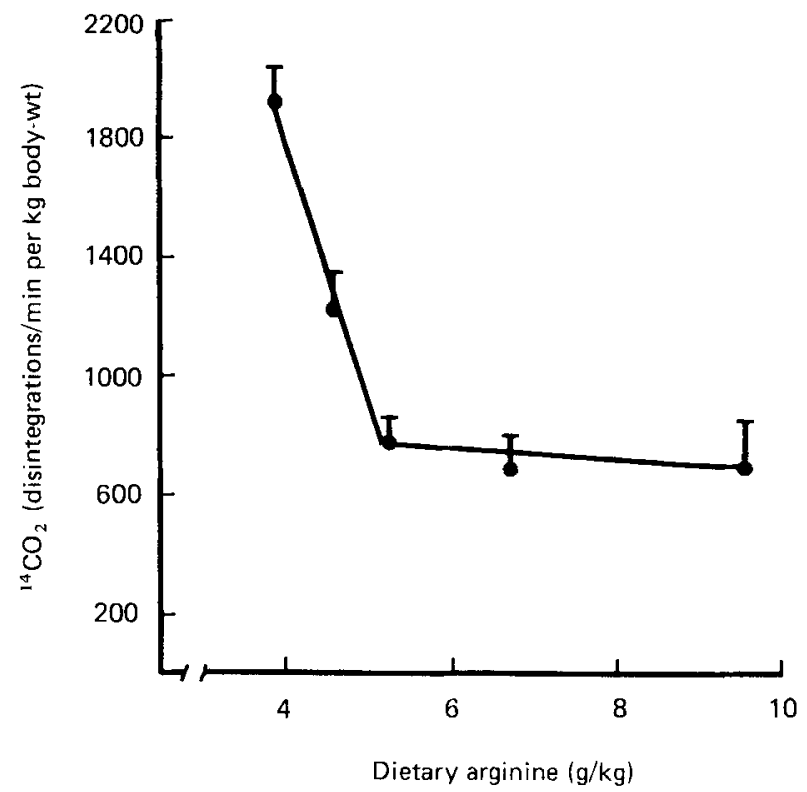

Fig. 4. Influence of arginine concentration in a diet containing $240 \mathrm{~g}$ crude protein (nitrogen $\times 6.25) / \mathrm{kg}$ on the oxidation of phenylalanine. Means with their standard errors, represented by vertical bars, for the radioactivity recovered as carbon dioxide in $1 \mathrm{~h}$ from pigs which had received two meals after an overnight fast. Each meal contained $10 \mu \mathrm{Ci} \mathrm{L}-\left[1-{ }^{14} \mathrm{C}\right]$ phenylalanine, $8.8 \mathrm{~g}$ phenylalanine $/ \mathrm{kg}$, $8 \cdot 5 \mathrm{~g}$ tyrosine $/ \mathrm{kg}$ and graded levels of arginine $(3 \cdot 9,4 \cdot 6,5 \cdot 3,6 \cdot 8,9 \cdot 6 \mathrm{~g} / \mathrm{kg})$. Each point represents the mean of four piglets except level $9.6(n 3)$. Lines were fitted by regression analysis. The means (with SE) for weight, age and growth rate of the piglets were $2.48(0.03) \mathrm{kg}, 12 \cdot 1(0.70) \mathrm{d}$ and $131(6 \cdot 0) \mathrm{g} / \mathrm{d}$ respectively. 
The results of the present study show that the young piglet requires a dietary proline concentration of $14 \mathrm{~g} / \mathrm{kg}$ in a diet supplying 0.4 of the $\mathrm{N}$ from skim milk and 0.6 of the $\mathrm{N}$ from free amino acids. This concentration of proline was supplied by the diet containing $240 \mathrm{~g}$ protein $/ \mathrm{kg}$ shown in the previous study to be the protein concentration necessary to minimize phenylalanine oxidation (Ball \& Bayley, 1986), suggesting that this response was to the proline supplied by the protein.

\section{Effect of dietary arginine concentration}

Adding arginine to a diet containing $200 \mathrm{~g}$ crude protein $/ \mathrm{kg}$ and an adequate proline concentration $(14.4 \mathrm{~g} / \mathrm{kg}$ ) increased phenylalanine oxidation (Fig. 3). However, increasing arginine from 3.9 to $5.3 \mathrm{~g} / \mathrm{kg}$, in a diet containing $240 \mathrm{~g}$ protein $/ \mathrm{kg}$, resulted in a reduction in the oxidation of phenylalanine (Fig. 4). These results indicate that an arginine concentration of $5.3 \mathrm{~g} / \mathrm{kg}$ was sufficient to minimize phenylalanine oxidation.

\section{DISCUSSION}

The lack of response to additions of lysine, threonine or methionine to the diet with an inadequate concentration of protein clearly shows that the requirement for these amino acids to maximize the retention of dietary protein was being met by a diet containing $200 \mathrm{~g}$ protein $/ \mathrm{kg}$ : half from skim milk and half from a mixture of free amino acids simulating skim milk. The liver radioactivity was not significantly affected by the addition of any of the amino acids, confirming the previous observation of Ball \& Bayley (1986) for piglets receiving the diets in which free amino acids provided 0.6 of the protein. These findings support the estimates of requirements for these amino acids by the NRC (1979) and the University of Guelph and suggest that the requirement for threonine and the sulphur amino acids calculated by the ARC (1981) are too high. There are several reports that adding methionine to skim-milk-based diets for the baby pig gives no positive response (Tate, 1974; Braude et al. 1977; Wilson \& Leibholz, 1981).

This is the first report of pigs responding to the addition of proline to their diets, although there are several reports that a dietary source of proline is necessary for maximum growth in the chick (Greene et al. 1962; Sugahara \& Ariyoshi, 1967; Graber \& Baker, 1973; Baker, 1977). Both glutamic acid and arginine have been established as metabolic precursors of proline in poultry (Austic, 1973) and mammalian species (Adams \& Frank, 1980). Thus the decrease in phenylalanine oxidation observed in the present experiments in response to the addition of the mixture of non-essential amino acids could have been due to an increased supply of glutamate to serve as a precursor of proline. Similarly, the response to the addition of arginine could be a result of its serving as a proline precursor. An alternative explanation of the results of Expt 1 is that proline was converted to arginine, suggesting that the response to proline was due to it serving as a substrate for arginine synthesis. However, proline supplementation seemed to cause a greater reduction in phenylalanine oxidation than arginine supplementation, suggesting a primary response to proline in the piglet weighing $2 \cdot 5 \mathrm{~kg}$.

Proline is the most abundant free amino acid in sow colostrum, accounting for $183 \mathrm{~g} / \mathrm{kg}$ free amino acids (Bengtsson, 1972). The concentration of proline in sow's milk is also high: $123 \mathrm{~g} / \mathrm{kg} \mathrm{N}$ (Elliot et al. 1971). In the unsuckled, newborn pig, free proline is low in plasma and serum relative to other amino acids (Cuperlovic, 1967; Bengtsson, 1971; Atkinson, 1977); however, after suckling, free proline increases fourfold in plasma and liver to become the most abundant free amino acid in these tissues (Bengtsson, 1972; Atkinson, 1977). Bengtsson (1972) suggested that these changes are even more dramatic considering the large increase in plasma volume which takes place during this period. 
Bengtsson \& Hakkarainen (1975) found a very rapid uptake of $\left[\mathrm{U}-{ }^{14} \mathrm{C}\right]$ proline following intramuscular injection in the newborn piglet, with a specific uptake by the muscular and skeletal systems. They concluded that the proline was being taken up for synthesis of the collagen matrix necessary for muscle development and mineralization of bone. A rapid disappearance of free proline in plasma and tissue has been shown in fasted 3-d- and 3-week-old pigs (Atkinson, 1977), suggesting that the high proline concentrations in liver, plasma and muscle were not due to a slow utilization of proline. Proline is oxidized slowly by mammalian tissues relative to other amino acids (Meister, 1965), and thus the disappearance must have been due to its incorporation into protein.

A high free-proline concentration in neonatal piglet tissue may be necessary for the synthesis of connective tissue and bone matrix. In the young animal, the collagen is more soluble, has a lower percentage of cross-linking and is more susceptible to proteolysis than later in life (Swatland, 1984). A high concentration of proline could serve to inhibit the turnover of connective-tissue protein during a period of life when the rate of turnover of other body protein is high, thus making the net synthesis of structural protein more rapid and efficient.

Expt 2 confirmed the response to dietary proline concentration and quantified the requirement to maximize the utilization of dietary amino acids for tissue growth. The results show that the piglet of $2.5 \mathrm{~kg}$, like the chick, is unable to synthesize proline rapidly enough to meet its requirements and thus requires a dietary supply of proline. Piglet tissue contains $67 \mathrm{~g}$ proline $/ \mathrm{kg}$ protein (Aumaitre \& Duee, 1974); the dietary requirement estimated in this study of $14 \mathrm{~g} / \mathrm{kg}$, in a diet containing $240 \mathrm{~g}$ protein $/ \mathrm{kg}$, corresponds to $58 \mathrm{~g}$ proline $/ \mathrm{kg}$ protein. This difference may indicate the extent of the piglet's limited capacity for proline synthesis. The failure to spare the proline requirement by addition of a full complement of amino acids to increase the dietary protein content to $260 \mathrm{~g} / \mathrm{kg}$ (Fig. 2) may not be surprising, since attempts with the chick to eliminate the proline requirement by feeding higher levels of glutamic acid (Graber et al. 1970; Bhargava et al. 1971), arginine or ornithine (Graber \& Baker, 1971; Austic, 1976) have also been unsuccessful.

The increase in phenylalanine oxidation in response to adding arginine to the diet containing $200 \mathrm{~g}$ protein $/ \mathrm{kg}$ in Expt 3 (Fig. 3) is atypical of the effects of increasing the concentration of an amino acid on the oxidation of phenylalanine. This response to arginine may indicate an imbalance of arginine relative to the supply of the other amino acids. Hays et al. (1959), in pigs initially weighing $3 \mathrm{~kg}$, showed that arginine supplementation to a basal diet containing $5 \mathrm{~g}$ arginine $/ \mathrm{kg}$ decreased growth. Although the differences in the protein content and the supplemental levels of the amino acids is small, younger animals are known to be more susceptible to amino acid imbalance than older animals (Harper et al. 1970). Easter \& Baker (1977) reported that excess arginine $(15 \mathrm{~g} / \mathrm{kg})$ decreased performance when pigs of $20 \mathrm{~kg}$ were given a diet deficient in protein $(120 \mathrm{~g} / \mathrm{kg})$, but not when a diet with adequate protein $(190 \mathrm{~g} / \mathrm{kg})$ was provided. This may explain why, in the present experiment, addition of arginine to the $200 \mathrm{~g}$ protein $/ \mathrm{kg}$ diet increased phenylalanine oxidation (Fig. 3) whereas the addition of arginine to the adequate protein diet $(240 \mathrm{~g} / \mathrm{kg})$ did not (Fig. 4). Southern \& Baker (1982) described adverse effects in pigs of 10-20 kg by the addition of only $6.7 \mathrm{~g}$ arginine $/ \mathrm{kg}$ to a practical diet and of $5 \mathrm{~g}$ arginine $/ \mathrm{kg}$ to a semi-purified diet. These authors found an increase in urinary excretion of lysine from 94 to $480 \mu \mathrm{mol} / 24 \mathrm{~h}$ and a significant depression in the plasma levels of lysine, histidine, proline, methionine and leucine. Rossell \& Zimmerman (1984) added $2 \cdot 2 \mathrm{~g}$ arginine $/ \mathrm{kg}$ to the diets of $40 \mathrm{~kg}$ pigs and found a significant increase in plasma urea concentration, perhaps indicating a facilitation of amino acid degradation. Taken together with the present results, these reports suggest that pigs are most susceptible to an arginine imbalance when they are younger and that the effect becomes less with increasing age. 
It is unlikely that the increase in phenylalanine oxidation as a result of adding arginine to the $200 \mathrm{~g}$ protein $/ \mathrm{kg}$ diet (Fig. 3) reflects a specific interaction of arginine with phenylalanine since they have no known pathways of metabolism or transport in common.

In contrast to the results shown in Fig. 3, increasing the arginine level in the diet containing $240 \mathrm{~g}$ protein $/ \mathrm{kg}$ produced values which allowed the estimation of the dietary arginine level necessary to minimize phenylalanine catabolism (Fig. 4). The results indicate that the $2.5 \mathrm{~kg}$ pig has an arginine requirement of $5.1 \mathrm{~g} / \mathrm{kg}$; higher than the NRC (1979) estimate of $3.3 \mathrm{~g} / \mathrm{kg}$ extrapolated from information on larger pigs. The arginine requirement of pigs of $10-20 \mathrm{~kg}$ has recently been estimated, using a semi-purified diet, as $4.8 \mathrm{~g} / \mathrm{kg}$ (Southern \& Baker, 1983), again higher than the current NRC (1979) estimate of $2.3 \mathrm{~g} / \mathrm{kg}$ for pigs of this weight range. Other reports (Hays et al. 1959; Leibholz, 1982), using diets with high basal arginine concentrations, 13.4 and $6.8 \mathrm{~g} / \mathrm{kg}$ respectively, have shown no positive response by the young pig to arginine supplementation.

The arginine requirement determined in Expt 3 of $5.1 \mathrm{~g} / \mathrm{kg}$ in a diet containing $240 \mathrm{~g}$ crude protein $/ \mathrm{kg}$ appears to conflict with the results of Expt 1 . A level of $5.1 \mathrm{~g}$ arginine would be supplied by a crude protein concentration of $160 \mathrm{~g} / \mathrm{kg}$ in the experimental diet, therefore a specific arginine deficiency does not explain the response observed in Expt 1 when arginine was added to the diet containing $200 \mathrm{~g}$ protein $/ \mathrm{kg}$. The response in Expt 1 to additions of arginine to an inadequate protein diet may have been due either to the uptake of arginine for the synthesis of another amino acid, such as proline, or to a limitation of arginine synthesis due to an inadequate supply of total non-essential amino N. However, since increasing protein concentrations from 200 to $260 \mathrm{~g} / \mathrm{kg}$, which then supplied $2 \cdot 13 \mathrm{~g}$ of additional arginine, did not reduce the proline requirement (Expt 2), this eliminates the first explanation. Adding a mixture of non-essential amino acids results in an apparent (but not statistically significant) decrease in phenylalanine oxidation, supporting the second possibility.

The increase in phenylalanine oxidation when arginine was added to the $200 \mathrm{~g}$ protein $/ \mathrm{kg}$ diet containing adequate proline (Fig. 3), suggests that proline may have been sparing the arginine requirement. Thus addition of arginine to an already more than adequate diet could create an excess. Supplementation of arginine to the higher protein diet (Fig. 4) did not increase phenylalanine oxidation, possibly due to a greater activity of the urea cycle since all amino acids except proline were in excess of their requirements. On the basis of these findings, if higher arginine levels had been studied in the diet containing $240 \mathrm{~g}$ protein $/ \mathrm{kg}$, phenylalanine oxidation would be expected to increase. In summary, the arginine requirement of the young pig appears to be sensitive to both total $\mathrm{N}$ and the amino acid composition of the diet.

The advice and guidance given by Drs E. T. Moran and T. K. Smith during the studies of which this research formed a part are gratefully acknowledged. The work was supported by the Natural Sciences and Engineering Research Council of Canada and the Ontario Ministry of Agriculture and Food.

\section{REFERENCES}

Adams, E. \& Frank, L. (1980). Annual Review of Biochemistry 49, 1005-1061.

Agricultural Research Council (1981). The Nutrient Requirements of Pigs. Slough: Commonwealth Agricultural Bureaux.

Atkinson, J. L. (1977). Substrate utilization and fasting metabolism during postnatal development of the pig. PhD Thesis, University of Guelph.

Aumaitre, A. \& Duee, P. H. (1974). Annales de Zootechnie 23, 231-236.

Austic, R. E. (1973). Journal of Nutrition 103, 999-1007.

Austic, R. E. (1976). Federation Proceedings 35, 1914-1916. 
Baker, D. H. (1977). In Advances in Nutritional Research, vol. 1, pp. 299-335 [H. H. Draper editor]. New York: Plenum Publishing Corporation.

Ball, R. O. \& Bayley, H. S. (1984). Journal of Nutrition 114, 1741-1746.

Ball, R. O. \& Bayley, H. S. (1986). British Journal of Nutrition 55, 651-658.

Bengtsson, S. G. (1971). Journal of Animal Science 32, 879-882.

Bengtsson, S. G. (1972). Acta Veterinaria Scandinavica 13, 7-13.

Bengtsson, S. G. \& Hakkarainen, R. V. J. (1975). Journal of Animal Science 41, 106-112.

Bhargava, K. K., Shen, T. F., Bird, H. R. \& Sunde, M. L. (1971). Poultry Science 50, 726-731.

Braude, R., Keal, H. D. \& Newport, M. J. (1977). British Journal of Nutrition 37, 187-194.

Cuperlovic, M. (1967). Acta Veterinaria Scandinavica 8, 217-227.

Easter, R. A. \& Baker, D. H. (1977). Journal of Animal Science 45, $108-112$.

Elliot, R. F., Vander Noot, G. W., Gilbreath, R. L. \& Fisher, H. (1971). Journal of Animal Science 32, $1128-1137$.

Graber, G., Allen, N. K. \& Scott, H. M. (1970). Poultry Science 49, 692-697.

Graber, G. \& Baker, D. H. (1971). Proceedings of the Society for Experimental Biology and Medicine 138, 585-588.

Graber, G. \& Baker, D. H. (1973). Poultry Science 52, 892-896.

Greene, D. E., Scott, H. M. \& Johnson, B. C. (1962). Poultry Science 41, 116-120.

Harper, A. E., Benevenga, N. J. \& Wohlhueter, R. M. (1970). Physiological Reviews 50, 428-5.58.

Hays, V. W., Speer, V. C., Hartman, P. A. \& Catron, D. V. (1959). Journal of Nutrition 69, $179-184$.

Kim, K. I. \& Bayley, H. S. (1983). British Journal of Nutrition 50, 383-390.

Kim, K. I., Elliot, J. I. \& Bayley, H. S. (1983a). British Journal of Nutrition 50, 391-399.

Kim, K. I., McMillan, I. \& Bayley, H. S. (1983b). British Journal of Nutrition 50, 369-382.

Leibholz, J. (1982). Australian Journal of Agricultural Research 33, 165-170.

Meister, A. (1965). Biochemistry of the Amino Acids, vol. 1. New York: Academic Press.

National Research Council (1979). Nutrient Requirements of Swine, 8th ed. Washington, DC: National Academy of Sciences.

Rossell, V. L. \& Zimmerman, D. R. (1984). Journal of Animal Science 59, 135-140.

Southern, L. L. \& Baker, D. H. (1982). Journal of Animal Science 55, 857-866.

Southern, L. L. \& Baker, D. H. (1983). Journal of Animal Science 57, 402-412.

Steel, R. D. G. \& Torrie, J. H. (1960). Principles and Procedures of Statistics with Special Reference to the Biological Sciences. New York: McGraw-Hill Book Co. Inc.

Sugahara, M. \& Ariyoshi, S. (1967). Agricultural and Biological Chemistry 31, 106-110.

Swatland, H. J. (1984). Structure and Development in Meat Animals. Englewood Cliffs, New Jersey: Prentice Hall Inc.

Tate, M. (1974). Studies on the utilization of amino acids by the neonatal pig. PhD Thesis, University of Aberdeen.

Wilson, R. H. \& Leibholz, J. (1981). British Journal of Nutrition 45, 301-319. 